\title{
SAMORZĄD TERYTORIALNY DROGĄ UPODMIOTOWIENIA SPOŁECZNOŚCl LOKALNYCH
}

Współczesne procesy globalizacyjne - wręcz ze swoistą determinacją - zmierzają do integracji czy jedności w sferze politycznej, ekonomicznej, kulturowej i społecznej. Autentyzm tych dążeń z samej swej istoty wydaje się być zjawiskiem pozytywnym. To m.in. zanikanie podziałów i dysproporcji, budzenie się solidarności międzyludzkiej czy podejmowanie wspólnych działań na rzecz określonych celów. Z tymi ostatnimi przedsięwzięciami sprawa nie jest jednak tak oczywista.

$Z$ drugiej strony trzeba jednocześnie dostrzegać niebezpieczeństwa, czy negatywne zjawiska, zwłaszcza $\mathrm{w}$ absolutyzacji integracji i jedności społeczeństwa, wręcz swoistego uniformizmu. To może w konsekwencji prowadzić nawet do praktycznego zatracenia, a nawet zniszczenia wszelkiej różnorodności w ramach życia społecznego czy kulturalnego.

W tym kontekście wyraźniej wybrzmiewa zagadnienie oraz istota i swoisty praktycyzm społeczności lokalnej i samorządu terytorialnego ${ }^{1}$.

* Urodzony 10 października 1950 r. w Pleszewie (archidiecezja gnieźnieńska). Wyświęcony na kapłana 21 czerwca 1975 r. w Gnieźnie. Mianowany biskupem łowickim 27 marca 2004 r. Konsekrowany 22 maja 2004 r. w Bazylice Katedralnej w Łowiczu. Przewodniczący Rady Naukowej Konferencji Episkopatu Polski. od 14 marca 2007 r. 
To pytania o kształt społeczności, jaką ludzie wykazują w codziennym życiu, w ich realiach życia. To wreszcie pytania o „obywatelską odpowiedzialność, uczestnictwo i demokratyczny sposób rządzenia"2. Zatem chodzi tutaj o wielkie sprawy odpowiedzialności społecznej i publiczne, które współcześnie podejmowane są z większą odpowiedzialnością i twórczym zaangażowaniem.

Sensem działania wszelkich instytucji w społeczeństwie i państwie jest służba podmiotowości społeczeństwa przez „tworzenie struktur uczestnictwa i współodpowiedzialności" ${ }^{3}$. Społeczność tylko w sferze faktycznego upodmiotowienia zdolna jest wziąć w swoje ręce problemy własnego środowiska, a jednocześnie skutecznie je rozwiązywać. Z drugiej strony lokalność wydaje się jedyną szansą bezpośredniej realizacji przez osobę ludzką jej twórczej podmiotowości w sferze wolności, aktywności i odpowiedzialności ${ }^{4}$.

Lokalność stanowi zatem warunek sine qua non właściwego dynamicznego i rozwojowego funkcjonowania życia społecznego poprzez upodmiotowienie wielorakich wspólnot, grup, bytów społecznych i poprzez pełne upodmiotowienie osoby ludzkiej stanowiącej podmiot życia społecznego. Zatem ważne jest miejsce spełniania demokratycznej odpowiedzialności społecznej.

\section{PROBLEMATYKA SAMORZĄDU TERYTORIALNEGO W NAUCZANIU SPOŁECZNYM KOŚCIOŁA}

Istnieje potrzeba jedności, integracji i solidarności w ramach życia społecznego, ale nie stoi ona w sprzeczności z różnorodnością i plurali-

${ }^{1}$ Por. J. Regulski, Samorząd terytorialny III Rzeczypospolitej. Koncepcje i realizacja, Warszawa 2000; M. Kulesza, Samorzad, w: Stownik społeczny, red. B. Szlachta, Kraków 2004, s. 1153-1175; H. Izdebski, M. Kulesza, Administracja publiczna. Zagadnienia ogólne, Warszawa 2001; K. Gurba, Samorzad, w: Encyklopedia nauczania społecznego Jana Pawła II, red. A. Zwoliński, Radom 2003, s. 448-451; B. Bubula, Samorzadowy poradnik wyborczy, Kraków 1998.

${ }^{2}$ D. Tusk, Królestwo ludzi wolnych, „Pomerania. Miesięcznik społeczno-kulturalny" 5:1986, s. 1; H. Skorowski, Samorząd terytorialny forma upodmiotowienia społeczeństwa, „Życie katolickie" 9, 1990, nr 7/8, s. 74.

3 Jan Paweł II. Encyklika Centesimus annus, Città del Vaticano 1991, nr. 46.

${ }^{4}$ Por. Spotkania z samorządami. Wypowiedzi Ojca Świętego Jana Pawła kierowane do wtadz lokalnych. Antologia, Warszawa 1997; T. Styczeń, Fundament etyczny państwa, w: Od solidarności do samorzadności. Jan Pawet II i wspólnoty lokalne, red. M. Starkowska, M. Rosalak, Warszawa 1999, s. 5-10. 
zmem w ramach współczesnego świata, a wręcz przeciwnie je zakłada i domaga się ich twórczej obecności. Taka sytuacja jest niezbędna dla zabezpieczenia i uszanowania podmiotowości wielorakich bytów społecznych w ramach szerszej społeczności, co oczywiście nie może także pomijać indywidualnych osób ${ }^{5}$.

Pojęcie podmiotowości oznacza z jednej strony wolność istnienia i działania wielorakich bytów społecznych, z drugiej zaś strony określoną płaszczyznę ich suwerenności w znaczeniu zarówno społecznym, ekonomicznym oraz kulturowym. Prawdziwa zatem podmiotowość wspólnot mniejszych, społeczności i grup w ramach organizmu państwowego, to możliwość swobodnego ich istnienia i działania, także autentycznego stanowienia o sobie we wszystkich płaszczyznach codziennej egzystencji, zwłaszcza że stanowią one zazwyczaj ważny element całości życia społecznego ${ }^{6}$.

Zagadnienie samorządu terytorialnego należy także widzieć w sferze jedności i integralności społeczności państwowej, a jednocześnie wielorakich form różnorodności i pluralizmu w ramach tej społeczności ${ }^{7}$. Pluralizm państwowy domaga się „wielostopniowej organizacji społecznej, powstawania pomiędzy jednostką a państwem szeregu społeczności pośrednich: zawodowych (korporacje), terytorialnych (samorząd terytorialny), klasowych (związki zawodowe), oświatowych (szkolnictwo prywatne), kulturalnych (stowarzyszenia), rodzinnych (rodzina hierarchiczna i związki rodzinne) ${ }^{\prime \prime}$. Czy jednak zawsze postulat ten znajduje pełne zrozumienie, a następnie praktyczną realizację?

Najbardziej właściwym sposobem faktycznego pluralizmu państwa jest istnienie i funkcjonowanie żywych i aktywnych społeczności terytorialnych oraz lokalnych. O ich istocie, podobnie jak o istocie państwa, stanowi wiele elementów i płaszczyzn: organizacyjna, świadomościowa, kulturalna, przestrzenna itp. Można zatem powiedzieć, że społeczności terytorialne są najbardziej zbliżone do państwa swym charakterem, a tym

${ }^{5}$ Por. Jan Paweł II, Encyklika Sollicitudo rei socialis, Città del Vaticano 1988, nr 14, 15; H. Skorowski, Etyczno-społeczne aspekty samorządu terytorialnego w świetle katolickiej nauki społecznej, „Życie katolickie” 9, 1990, nr 5/6, s. 13-14; A. Porawski, Polityka regionalna, w: Od solidarności do samorządności, s. 22-26.

${ }^{6}$ Por. Jan Paweł II, Poszanowanie mniejszości warunkiem pokoju. Orędzie na XXII Światowy Dzień Pokoju 1.01.1989, Warszawa 1989, nr 5-8.

7 Por. Cz. Strzeszewski, Katolicka nauka społeczna, Warszawa 1985, s. 514.

8 Tamże. 
samym najbardziej właściwym sposobem funkcjonowania pluralizmu państwowego w realnej rzeczywistości kulturowej, społecznej i często geograficznej ${ }^{9}$.

W ten sposób z jednej strony najbardziej właściwym, z drugiej zaś strony najbardziej rozpowszechnionym systemem decentralizacji państwa jest samorząd terytorialny. To jest fundamentalne rozeznanie struktur życia społecznego, w płaszczyźnie zwłaszcza administracyjnej. Posiada on trzy zasadnicze cechy: łączy wszystkich mieszkańców danego terytorium, co nadaje mu charakter powszechności; jego celem jest dobro ogólne ludności zamieszkałej na jego terytorium, co nadaje mu charakter wszechstronności; posiada władzę, która może domagać się posłuszeństwa $^{10}$. Dobro wspólne to zwłaszcza „suma warunków życia społecznego, jakie bądź zrzeszeniom, bądź poszczególnym członkom społeczeństwa pozwalają osiągnąć pełniej i łatwiej własną doskonałość"11.

Na szczeblu najwyższym samorządność terytorialna może przybierać charakter autonomii wielkich okręgów terytorialnych, która może łączyć się z autonomią narodowościową, etniczną i regionalną. Niższe szczeble samorządności mogą ujawniać się w autonomii powiatów, gmin, wsi, sołectw. Odpowiednie szczeble samorządu miejskiego to: miasto, dzielnica, blok itp. To jest niezwykłe bogactwo ludzi - czasem trudne do podjęcia - które jednak trzeba dostrzegać, rozeznawać oraz - jeśli zachodzi konieczność - wcielać w praktykę życia społecznego.

Samorząd terytorialny jest odtworzeniem i utrwaleniem naturalnej ewolucji historycznej rozwoju form uspołecznienia. „Dzięki niemu zostają złączone całym szeregiem społeczności pośrednich dwie społeczności zasadnicze, naturalne i konieczne, jakimi są rodzina i państwo"12. Samorząd terytorialny oznacza rządzenie się mniejszej społeczności na podstawie ustanowionych przez nią zasad, to znaczy prawami ustanowionymi przez

${ }^{9}$ Por. J. Iskierski, Lokalność czy powrót do raju utraconego, „Pomerania. Miesięcznik społeczno-kulturalny" 7, 1987 s. 1; Cz. Strzeszewski, Katolicka nauka społeczna, s. 527-528.

${ }^{10}$ Por. J. Iskierski, Lokalność, s. 2; Cz. Strzeszewski, Katolicka nauka społeczna, s. 528.

${ }^{11}$ Sobór Watykański II, Konstytucja duszpasterska o Kościele w świecie wspótczesnym, w: Sobór Watykański II, Konstytucje, dekrety, deklaracje, Poznań 1968, nr 26. Dobro wspólne można określić jako „wartość społeczno-moralna , której treścią jest pełnia osobowego rozwoju wszystkich członków społeczeństwa, realizowana przez nich wspólnie, w oparciu o naturalne właściwości ludzkie i instytucjonalne warunki społeczne" (J. Kondziela, Filozofia spoteczna. Zagadnienia wybrane, Lublin 1972, s. 31). Por. J. Krucina, Dobro wspólne. Teoria $i$ jej zastosowanie, Wrocław 1972.

${ }^{12}$ Cz. Strzeszewski, Katolicka nauka społeczna, s. 529. 
nią samą w ramach nadrzędnej struktury danego społeczeństwa państwowego. Tak rozumiana samorządność stoi w ścisłej relacji z niezależnością. Można powiedzieć, że samorządność i niezależność są dwoma aspektami tej samej wartości, jaką jest autonomia, i wzajemnie się warunkują ${ }^{13}$.

Tak rozumiany samorząd terytorialny, czy samorządzenie się mniejszej społeczności w ramach społeczności państwowej, stojące z kolei w ścisłej relacji z niezależnością, oznacza w konsekwencji, iż staje się on „przestrzenią” obrony i urzeczywistniania przez wielorakie społeczności, a idąc jeszcze dalej, przez jednostki ludzkie swej twórczej podmiotowości. W ten sposób staje się on „przestrzenią” wolności, aktywności i odpowiedzialności.

W tym kontekście szczególnie wymowna jest myśl Soboru Watykańskiego II, który wyraża zachętę: „rządzący niech baczą, by nie stawiać przeszkód społecznościom rodzinnym, związkom społecznym i kulturalnym, zarządom i instytucjom pośrednim, i niech nie pozbawiają ich legalnej i pożytecznej działalności, ale raczej niech starają się chętnie i ustawicznie je popierać"14.

\section{ANTROPOLOGICZNE PODSTAWY SAMORZĄDU TERYTORIALNEGO}

Samorządność struktur pośrednich, jakimi są niewątpliwie społeczności terytorialne, opiera się na zasadzie pomocniczości ${ }^{15}$. Zresztą zasada ta jest fundamentem funkcjonowania demokratycznego państwa, co wskazuje preambuła Konstytucji RP z 1997 r.: „ustanawiamy Konstytucję RP jako prawa podstawowe dla państwa oparte na poszanowaniu wolności i sprawiedliwości, współdziałaniu władz, dialogu społecznym

${ }^{13}$ Por. H. Skorowski, Etyczno-spoteczne aspekty samorzadu terytorialnego, s. 16.

${ }^{14}$ Sobór Watykański II, Konstytucja duszpasterska o Kościele w świecie wspótczesnym, nr 75. Por. K. Gurba. Samorzad, s. 450.

15 „Należy tu starannie wyjaśnić podstawy tej zasady. Otóż, opiera się ona na fakcie, że każdy człowiek jest inny; każdy jest osobą. Każdy człowiek jest jedyny w swoim rodzaju; każdy jest źródłem swej oryginalności i posiada coś, co może ofiarować innym ludziom, a tym samym całej wspólnocie. [...]. Człowiek nie tylko ma coś do zaofiarowania innym, ale ma prawo oczekiwać tego samego od innych. Nie możemy być zupełnie sami - każdy powinien żyć tak, aby być dobrodziejstwem dla drugiego i dla całej ludzkości" (M. Schooyans, Initiation... l'enseignerment social de l'Eglise, Paris 1992, s. 45-46). Por. C. Ritter, Etos demokracji, w: Od solidarności do samorząności, s. 30-32; M. Leśniak, Pomocniczość, w: Encyklopedia nauczania społecznego Jana Pawta II, s. 377-381; Ch. Millon-Delson, Zasada pomocniczości, Kraków 1995. 
oraz na zasadzie pomocniczości umacniającej uprawnienia obywateli i ich wspólnot"16.

Jako zasada ontologiczna wskazuje ona, że jedynym bytem osobowym i samodzielnym jest osoba ludzka. Społeczność jest zarazem bytem istniejącym przez i dla człowieka ${ }^{17}$. Oznacza to, że osoba ludzka i jej rozwój jest jedynym celem społeczności, to znaczy że społeczność ma charakter służebny i celowy. Jeśli zatem mniejsza społeczność potrafi zaspokoić potrzeby osoby ludzkiej, to nie ma potrzeby naturalnej do powstawania społeczności szerszej ${ }^{18}$. Im mniejsza społeczność, tym bardziej może być przesiąknięta pierwiastkiem osobowym, a tym samym bliższa staje się osobie ${ }^{19}$.

Zasada pomocniczości jako zasada prawna wskazuje z kolei, że prawa osoby są źródłem wszystkich praw społecznych, praw wszystkich społeczności. Stąd też „wszystkie społeczności mają samodzielne, niezależnie od siebie prawa ugruntowane w prawie naturalnym poprzez naturę człowieka. [...] Każda [...] społeczność wyższa musi szanować prawo społeczności niższych, podobnie jak każda społeczność winna szanować prawa osoby ludzkiej"20.

Zasada pomocniczości jest wreszcie zasadą etyczną. Jeżeli osoba ludzka jest celem życia społecznego, to jej dobro jest treścią dobra społecznego i normą moralności społecznej. Można zatem powiedzieć, że z jednej strony dobro osobowe jest źródłem dobra ogólnego, z drugiej zaś strony każda osobowość ma własne dobro niezależne od dobra innych społeczności.

Tak rozumianą zasadę pomocniczości w jej wymiarze ontologicznym, prawnym i etycznym, można ujać w haśle: „Tyle wolności ile można, tyle uspołecznienia ile koniecznie potrzeba; tyle społeczeństwa, ile

16 „Istota ludzka określa się bardziej przez to, co czyni niż przez to co, co uzyskała czy nawet posiada. Stąd konsekwencja: w społeczności politycznej należy uczynić wszystko, by nikt nie był pozbawiony możliwości działania, które sam może i chce podjąć" (Ch. Millon-Delosol, Zasada pomocniczości, Kraków 1995, s. 8).

${ }^{17}$ Por. Pius XI, Encyklika Quadragesimo anno, w: Dokumenty nauki społecznej Kościoła, cz. 1, red. M. Radwan i inni, Rzym-Lublin 1996, nr 79; Cz. Strzeszewski, Katolicka nauka spoteczna, s. 512; K. Gurba, Samorzą, s. 450; J. Majka, Filozofia społeczna, Warszawa 1982, s. $165-167$.

${ }^{18}$ Por. Cz. Strzeszewski, Katolicka nauka spoteczna, s. 512.

${ }^{19}$ Por. H. Skorowski, Etyczno-spoteczne aspekty samorządu terytorialnego, s. 16-17.

${ }^{20}$ Cz. Strzeszewski, Katolicka nauka spoteczna, s. 513. Por. H. Skorowski, Etyczno-społeczne aspekty samorzadu terytorialnego, s. 17-18. 
można, tyle państwa, ile koniecznie trzeba"21. Zatem „społeczność wyższego rzędu nie powinna ingerować w wewnętrzne sprawy społeczności niższego rzędu, pozbawiając ją kompetencji, lecz raczej winna wspierać ją w razie konieczności i pomóc w koordynacji jej działań z działaniami innych grup społecznych, dla dobra wspólnego" ${ }^{\prime 22}$. To ona nie tylko zapewnia ale wręcz domaga się możliwości tworzenia wielostopniowych struktur społecznych i szeroko rozumianych struktur samorządowych dla dynamizmu i sprężystości społeczeństwa ${ }^{23}$.

Przypominając szczególną rolę zasady pomocniczości, Jan Paweł II podkreśla zadanie społeczności pośrednich w uruchamianiu swojego rodzaju systemu solidarności. „Dojrzewają one jako prawdziwe wspólnoty osób i umacniają tkankę społeczną, zapobiegając jej degradacji, jaka jest anonimowość i bezosobowe umasowienie, niestety często we współczesnym społeczeństwie. Osoba ludzka żyje i «podmiotowość społeczeństwa» wzrasta wtedy, kiedy wiele różnych relacji wzajemnie się ze sobą splata"24.

Zasadę pomocniczości należy uznać za zasadę mieszczącą się w zasadzie personalizmu, która określa, definiuje i wyznacza funkcjonowanie społeczeństwa, aby osoba w swej godności mogła być zabezpieczona i uszanowana. Ponieważ implikuje ona wolność i domaga się jej realizacji w życiu społecznym, stąd warunkuje i uzasadnia istnienie samorządu ${ }^{25}$. Zatem należy ją uznać za najbardziej podstawową i najwyższą rację porządkującą, organizującą i wyznaczającą właściwe struktury społeczeństwa, a więc wpisana jest ona w funkcjonowanie samorządu terytorialnego.

${ }^{21}$ Cz. Strzeszwski, Katolicka nauka spoteczna, s. 513-514. Por. H. Skorowski, Etyczno-spoteczne aspekty samorzadu terytorialnego, s. 18.

${ }^{22}$ Jan Paweł II. Encyklika Centesimus annus, nr 48.

23 „Nienaruszalnym i niezmiennym pozostaje owo najwyższe prawo filozofii społecznej: co jednostka z własnej inicjatywy i własnymi siłami może zdziałać, tego jej nie wolno wydzierać na rzecz społeczeństwa; podobnie niesprawiedliwością, szkodą społeczną i zakłóceniem ustroju jest zabieranie mniejszym i niższym społecznościom tych zadań, które mogą spełnić, i przekazywanie ich społecznościom większym i wyższym. Każda akcja społeczna ze swego celu i ze swej natury ma charakter pomocniczy; winna pomagać członkom organizmu społecznego, a nie niszczyć ich lub nie wchłaniać" (Pius XI, Encyklika Quadragesimo anno, nr 79); por. J. Majka, Filozofia społeczna, s. 172.

${ }^{24}$ Jan Paweł II. Encyklika Centesimus annus, nr 49. Por. K. Gurba, Samorząd, s. 450; H. Skorowski, Wolność, integracja, solidarność w nauczaniu Jana Pawła II, Warszawa 2002; J. Tischner, Etyka solidarności, Kraków 1981.

${ }^{25}$ Por. J. Majka, Filozofia społeczna, s. 168. 
Jan Paweł II wyraźnie przypomina, że „interweniując bezpośrednio i pozbawiając społeczeństwo odpowiedzialności, państwo opiekuńcze powoduje utratę ludzkich energii i przesadny wzrost publicznych struktur, w których - przy ogromnych kosztach - raczej dominuje logika biurokratyczna aniżeli troska o to, by służyć korzystającym z nich ludziom. Istotnie, wydaje się, że lepiej zna i może zaspokoić potrzeby ten, kto styka się z nimi z bliska i kto czuje się bliźnim człowieka potrzebującego. Przy tym często pewnego rodzaju potrzeby wymagają odpowiedzi wykraczającej poza porządek tylko materialny, takiej mianowicie, która potrafi wyjść naprzeciw głębszym potrzebom ludzkim"26.

Źródłem właściwego funkcjonowania społeczeństwa jest personalistyczna koncepcja samego społeczeństwa. Osoba ludzka nie jest tutaj tylko wpisana $\mathrm{w}$ życie społeczne i wszystkie procesy historyczne, kulturowe, społeczne i polityczne mają do niej odniesienie, ale przede wszystkim jest ona ostatecznym i podstawowym podmiotem społeczności. Dlatego Jan Paweł II wskazuje: „Podstawą i celem porządku społecznego jest osoba ludzka [...]. Osoba jest czymś, co wyrasta ponad uwarunkowania społeczne, kulturowe i historyczne, bowiem właśnie człowiek, istota obdarzona duszą, dąży do celu, który pozostaje transcendentny wobec zmiennych warunków jego egzystencji" ${ }^{\prime 27}$. Podobną myśl już wcześniej podejmuje Sobór Watykański II: „Osoba ludzka jest i powinna być zasada, podmiotem i celem wszystkich urządzeń społecznych, ponieważ z natury swej potrzebuje ona życia społecznego" ${ }^{28}$.

Personalistyczna koncepcja społeczności zakłada i uznaje zatem, że jedynym bytem osobowym jest człowiek. Każda społeczność jest tylko rzeczywistością porządku, a więc istnieje przez i dla człowieka. Jedynym celem społeczności jest osoba ludzka, jej doskonalenie i osiąganie przez nią szczęścia ${ }^{29}$. Personalistyczna koncepcja społeczności wyraża zatem prawdę o pierwszeństwie i autonomii człowieka w życiu społecznym, to znaczy, że ramy społeczności są przestrzenią stawania się i realizacji człowieka-osoby. Zatem zasada personalizmu jest konsekwencją per-

\footnotetext{
${ }^{26}$ Jan Paweł II, Encyklika Centesimus annus, nr 48.

${ }^{27}$ Jan Paweł II, Wolność religijna warunkiem pokojowego wspótżycia. Orędzie na XXI Światowy Dzień Pokoju 1.01.1988, Warszawa 1988, nr 5.

${ }^{28}$ Sobór Watykański II, Konstytucja duszpasterska o Kościele w świecie wspótczesnym, nr 25.

${ }^{29}$ Por. Cz. Strzeszewski, Katolicka nauka społeczna, s. 512; K. Wojtyła, Osoba i czyn, Kraków 1969; W. Granat, Personalizm chrześcijański. Teologia osoby ludzkiej, Poznań 1985; K. Wojtyła, Miłość i odpowiedzialność, Lublin 1960.
} 
sonalistycznej koncepcji społeczeństwa, które jest przez człowieka i dla człowieka, które jest przestrzenią realizacji jego osobowej godności ${ }^{30}$.

Zatem człowiek w swej godności jest najgłębszą podstawą samorządu terytorialnego. To z niej wypływa oczekiwanie, aby życie społeczne było oparte na zasadzie personalizmu. Ta zasada porządkuje cały system społeczny na miarę wielkości i godności osoby. Wreszcie mieści ona w sobie zasady bardziej szczegółowe, tzn. zasadę pomocniczości i pluralizmu, które bezpośrednio zabezpieczają istnienie i funkcjonowanie samorządu terytorialnego ${ }^{31}$.

Za najgłębszą zatem teoretyczną podstawę samorządu terytorialnego należy uznać samego człowieka w jego godności. Ta godność domaga się ułożenia życia społecznego na podstawie takich zasad, które umożliwiać będą funkcjonowanie szerokiego wachlarza społeczności, takich społeczności, które człowiek może „ogarnąć” i dzięki którym odnajduje swój „przydział”, a przez nie ostatecznie realizuje siebie w swej twórczej podmiotowości. Zatem najgłębsze podstawy samorządu terytorialnego tkwią w płaszczyźnie antropologiczno-personalistycznej.

\section{AUTONOMIA SPOŁECZNOŚCl LOKALNYCH}

Jeśli przyjąć, że zasadniczą ideą, na której opiera się samorząd, jest idea autonomii regionu $\mathrm{w}$ ramach większego społeczeństwa, to jest to w konsekwencji zawsze autonomia określonej społeczności lokalnej. Chodzi o to, by było miejsce dla podmiotowości środowisk lokalnych, by sfera ogólnopaństwowa nie obejmowała i szczegółowo nie normowała całego obszaru życia społecznego ${ }^{32}$. Rzeczywista zatem autonomia jest podstawowym i nieodzownym warunkiem podmiotowości społeczności lokalnej.

Na bazie faktycznej autonomii wspólnota lokalna tworzy wielorakie struktury, w których ujawnia się jej rzeczywiste zarządzanie i rządzenie regionem w wielu płaszczyznach, co oznacza pełne upodmiotowanie. Podmiotowość oznacza z jednej strony wolność istnienia określonych

${ }^{30}$ Por. H. Skorowski, Etyczno-spoteczne aspekty samorząu terytorialnego, s. 19-20.

${ }^{31}$ Por. J. Majka, Filozofia spoteczna, s. 172; H. Skorowski, Samorzad terytorialny forma upodmiotowienia społeczeństwa, s. 71-73, 78-80.

${ }^{32}$ Por. J. Mazewski, Samorząność lokalna, „Pomerania. Miesięcznik społeczno-kulturalny" 6, 1989, s. 5-6; H. Skorowski, Samorząd terytorialny szkota uobywatelnienia jednostki, „Życie katolickie” 9, 1990, nr 9/10, s. 38; tenże, Samorząd terytorialny forma upodmiotowienia społeczeństwa, s. 79-80. 
bytów społecznych, z drugiej zaś strony płaszczyznę suwerennych decyzji i działania w sferze politycznej, gospodarczej, kulturowej i społecznej, które określić można demokratycznym sposobem rządzenia. W praktyce daje to poszczególnym społecznościom lokalnym szeroki wachlarz decyzji i działań stanowiących o ich własnym stylu życia i funkcjonowania. Chodzi o to, aby ludzie „stali się budowniczymi nowego, ewangelicznego ładu wolności : wewnątrz nas samych, a także w społecznościach, w których przyszło nam żyć i pracować" ${ }^{\prime \prime 3}$.

Upodmiotowienie społeczności lokalnej poprzez samorząd oznacza aktywność polityczną ${ }^{34}$, także w podejmowaniu „odpowiedzialności za sprawy publiczne, $\mathrm{w}$ duchu troski o przyszłość narodu, budowaną na prawdzie Ewangelii" ${ }^{\prime 35}$. To przede wszystkim pełny udział w rozstrzyganiu i decydowaniu o sprawach zbiorowości lokalnej dla dobra jej członków i całej wspólnoty, to udział w faktycznym sprawowaniu władzy we własnym regionie, ale także $\mathrm{w}$ całym społeczeństwie, $\mathrm{w}$ jej kreowaniu i kontroli nad nią, w określaniu jej treści i zadań.

W praktyce oznacza to, że aktywność polityczna społeczności lokalnej „wyraża się nie tylko w afirmacji i współdziałaniu z jakąś siłą polityczną $\mathrm{w}$ ogóle, czy w konkretnej sprawie, ale również $\mathrm{w}$ nieafirmowaniu programu i posunięć, do których ma się zastrzeżenia, w nieuczestniczeniu $\mathrm{w}$ działaniach, które ocenia się negatywnie z punktu widzenia etycznego i społecznego, $w$ rezygnacji z funkcji i członkostwa w strukturach, do których pozytywnej roli nie ma się przekonania"36. Tak rozumiana aktywność polityczna jest istotnym przejawem upodmiotowienia społeczności lokalnej. Rezygnacja $\mathrm{z}$ niej to $\mathrm{w}$ istocie rzeczy rezygnacja z własnej podmiotowości ${ }^{37}$.

Pełne upodmiotowanie wspólnoty lokalnej poprzez samorząd, to także szeroki wachlarz własnych decyzji i działań w sferze gospodarczej

${ }^{33}$ Jan Paweł II, Homilia podczas Mszy świętej na zakończenie Międzynarodowego Kongresu Eucharystycznego, Wrocław. 1.06.1997, w: Pielgrzymka Apostolska Ojca Świętego Jana Pawła II do Polski. 31.05.1997-10.06.1997, Poznań 1997, s. 29.

${ }^{34}$ Por. H. Skorowski, Samorzą terytorialny forma upodmiotowienia społeczeństwa, s. 79; H. Galus, Podmiotowość, „Pomerania. Miesięcznik społeczno-kulturalny” 12, 1986, s. 2; H. Skorowski, Samorzą terytorialny szkota uobywatelnienia jednostki, s. 39.

${ }^{35}$ Jan Paweł II, Przemówienie podczas liturgii stowa. Gorzów Wielkopolski. 2.06.1997, w: Pielgrzymka Apostolska Ojca Świętego Jana Pawła II do Polski, s. 50-51.

${ }^{36}$ H. Galus, Podmiotowość, s. 3. Por. H. Skorowski, Samorzad terytorialny szkotg uobywatelnienia jednostki, s. 39-40.

${ }^{37}$ Por. H. Skorowski, Etyczno-spoteczne aspekty samorzadu terytorialnego, s. 21-22. 
i ekonomicznej. Daje to społeczności lokalnej możliwość decydowania o obliczu gospodarczym własnego regionu, podejmowania działań mających na celu właściwe wykorzystanie naturalnych dóbr i wartości, zagospodarowanie terenu zgodnie $\mathrm{z}$ własnymi tradycjami i najlepiej pojętym interesem społeczności miejscowej. Możliwość ta winna przejawiać się w dążeniu do jak najlepszego zagospodarowania miejscowych zasobów naturalnych, niedopuszczania do marnowania się ziemi i upraw, do ciągłego dynamizowania rozwoju dóbr ekonomicznych, ulepszania struktur gospodarczych własnego regionu ${ }^{38}$.

Faktyczna podmiotowość społeczności lokalnej to także sfera samostanowienia $\mathrm{w}$ płaszczyźnie szeroko rozumianej kultury. Samostanowienie i samorządność w sferze kultury domaga się istnienia wielu samorządowych, autentycznych i równoprawnych podmiotów kultury. Cała społeczność winna być autentycznym, samorządnym podmiotem kultury. Zatem społeczność ta sama decyduje o kultywowaniu, ale także rozwoju i ubogacaniu własnej kultury lokalnej, układaniu i kształtowaniu sposobu życia w oparciu o wartości własnej tradycji kulturowej, o własnych inicjatywach artystycznych i naukowych. Daje to wspólnocie lokalnej także prawo do regionalizacji treści nauczania i kształcenia $\mathrm{w}$ szkole. Ma to m.in. pomagać $\mathrm{w}$ zapobieżeniu wyobcowaniu ze swego najbliższego regionu społeczno-kulturowego ${ }^{39}$.

Upodmiotowienie społeczności lokalnej poprzez samorząd daje jej szeroki wachlarz decyzji i działań stanowiących o jej własnym stylu i funkcjonowaniu w ramach większej społeczności państwowej. Rzeczywista zaś autonomia i suwerenność w decyzjach i działaniu w regionie i na rzecz regionu jest faktycznym i realnym upodmiotowieniem określonego bytu społecznego.

\section{SAMORZĄD TERYTORIALNY "MIEJSCEM" REALIZACJI PODMIOTOWOŚCl OSOBY}

Faktyczne upodmiotowienie społeczności lokalnej poprzez samorząd jest ostatecznie stworzeniem osobie ludzkiej „przestrzeni” realizacji

${ }^{38}$ Por. J. M. Miąskowski, Kto się boi lokalnego patriotyzmu?, „Pomerania. Miesięcznik społeczno-kulturalny" 4:1983, s. 10-11.

${ }^{39}$ Por. H. Galus, Szkoła i region, "Pomerania. Miesięcznik społeczno-kulturalny” 5, 1986, s. 4 . 
jej twórczej podmiotowości. Zagadnienie realizacji przez osobę jej podmiotowości stoi w ścisłej relacji z jej aktywnością. Można powiedzieć, że realizacja podmiotowości dokonuje się poprzez całą sferę aktywności i działania człowieka. W sferze aktywności człowiek bowiem realizuje siebie. Jest ona właściwą formą istnienia osoby, jako istoty ontologicznie dynamicznej ${ }^{40}$.

Pierwsza encyklika Jana Pawła II Redemptor hominis przypominała: "Człowiek w całej prawdzie swego istnienia: bycia osobowego i zarazem «wspólnotowego», i zarazem «społecznego» - w obrębie własnej rodziny, w obrębie tylu różnych społeczności, środowisk [...], w obrębie całej ludzkości - ten człowiek jest pierwsza drogą, po której winien kroczyć Kościół w wypełnianiu swego posłannictwa, jest pierwszą i podstawową drogą Kościoła, drogą wyznaczoną przez samego Chrystusa" ${ }^{41}$.

Człowiek jako istota dynamiczna musi mieć możliwość manifestowania siebie $\mathrm{w}$ działaniu $^{42}$. Takie warunki manifestowania siebie w działaniu stwarza samorząd terytorialny poprzez pełne upodmiotowienie społeczności lokalnej. Czyni to niejako w dwóch płaszczyznach: $\mathrm{z}$ jednej strony upodmiotowione własne środowisko lokalne pobudza i aktywizuje człowieka, z drugiej zaś strony stwarza mu wielorakie sfery i możliwości pełnej aktywności.

W szeroko pojętej działalności społeczności lokalnej, wspólnoty terytorialnej w sferze politycznej, ekonomicznej, gospodarczej, kulturowej itp. należy widzieć jej oddziaływanie na aktualność konkretnej jednostki ludzkiej. Nie ulega bowiem wątpliwości, że działalność wspólnoty, którą człowiek jest $\mathrm{w}$ stanie ogarnąć, którą uznaje za swoją i z która się faktycznie identyfikuje, jest dla człowieka inspirująca i pobudzająca ${ }^{43}$.

Aktywizacja człowieka pod wpływem społeczności nie dokonuje się automatycznie poza sferą świadomości człowieka. Stąd ważkość poczucia identyfikacji ze społecznością lokalną. Biorąc jednak pod uwagę, że społeczność ta daje człowiekowi poczucie „zakorzenienia”, należy stwierdzić, że jej dynamizm w działaniu będzie zawsze inspirujący dla osoby, która w niej tkwi.

${ }^{40}$ Por. H. Skorowski, Etyczno-spoteczne aspekty samorządu terytorialnego, s. 23-24; J. Czajkowski, Człowiek w nauce Jana Pawła II, Rzym 1983; S. Kowalczyk, Człowiek, społeczeństwo, ustrój, Lublin 1995; R. Spaeman, Osoby. O różnicy między czymś a kimś, Warszawa 2001.

${ }^{41}$ Jan Paweł II, Encyklika Redemptor hominis, Città del Vaticano 1979, nr 14.

${ }^{42}$ Por. R. Dubos, Pochwała różnorodności, Warszawa 1986, s. 270.

${ }^{43}$ Por. H. Skorowski, Etyczno-spoteczne aspekty samorzadu terytorialnego, s. 23-24. 
Osoba ludzka jest ciągle i na nowo inspirowana szeroką płaszczyzną działalności własnej wspólnoty, która w syntezie z własnym poczuciem odpowiedzialności osoby ukształtowanym na bazie zakorzenienia i identyfikacji z własną wspólnotą, wyzwala faktyczną aktywność jednostki. W praktyce aktywizacja przez własną upodmiotowioną społeczność lokalną, może i faktycznie przejawia się $\mathrm{w}$ wielu formach i płaszczyznach. Okazuje się, że w pełni upodmiotowiona społeczność lokalna stwarza osobie szeroką "przestrzeń” realizacji własnego osobowego dynamizmu w konkretnym działaniu.

Wiadomo, że na bazie autonomii regionu wspólnota lokalna tworzy własne struktury, w których ujawnia się jej rzeczywiste działanie $\mathrm{w}$ regionie i na rzecz regionu $\mathrm{w}$ sferze ekonomicznej, gospodarczej, kulturowej, społecznej i politycznej. Tworzy ono w ten sposób niejako „przestrzeń", w której konkretna jednostka potrafi się odnaleźć i działać w zależności od posiadanych uzdolnień i zainteresowań. Może to czynić bądź w sferze kulturowej poprzez własną twórczość, kultywowanie i rozwijanie wielorakich wartości własnej lokalnej kultury, bądź w sferze ekonomiczno-gospodarczej $\mathrm{w}$ formie działania na rzecz ekonomicznego rozwoju własnego środowiska ${ }^{44}$.

Dlatego Jan Paweł II przypominał w Krakowie: „Wierność korzeniom jest zawsze twórcza, gotowa do pójścia w głąb, otwarta na nowe wyzwania, wrażliwa na «znaki czasu». Wyraża się ona także w trosce o rozwój rodzimej kultury, w której wątek chrześcijański obecny był od samego początku. Wierność korzeniom oznacza nade wszystko umiejętność budowania organicznej więzi między odwiecznymi wartościami, które tylekroć sprawdziły się w historii, a wyzwaniami współczesnego świata, między wiarą a kulturą, między Ewangelią a życiem"45.

Jednostka ludzka może odnaleźć własne miejsce i realizować siebie w sferze politycznej, poprzez udział w rozstrzyganiu spraw zbiorowości lokalnej dla dobra jej członków i całej wspólnoty, przez udział w sprawowaniu władzy, w jej kreowaniu i kontroli, w określaniu treści jej zdań itp. Nie ulega zatem wątpliwości, że upodmiotowiona w samorządzie społeczność lokalna stwarza szerokie warunki i możliwości realizowania przez osoby jej dynamizmu w konkretnym działaniu. Przecież „" «państwo społeczne» bazuje na «subsydiarnej solidarności» jednostek i grup

${ }^{44}$ Por. tamże, s. 24.

${ }^{45}$ Jan Paweł II, Przemówienie pożegnalne, Kraków. 10.06.1997, w: Pielgrzymka Apostolska Ojca Świętego Jana Pawła II do Polski, s. 170-171. 
społecznych, dlatego żadna reforma strukturalna nie obejdzie się bez jednoznacznej odbudowy zachowań prospołecznych, bez wyzwolenia oddolnej aktywności jednostkowej i wspólnotowej"46.

W ten sposób należy ujmować oddziaływanie społeczności lokalnej na możliwość realizowania przez osobę jej twórczej podmiotowości. Wspólnota ta $\mathrm{z}$ jednej strony inspiruje osobę własnym dynamizmem, z drugiej zaś strony zabezpiecza i gwarantuje jednostce wiele płaszczyzn pełnego zaangażowania. A ponieważ upodmiotowienie wspólnoty lokalnej jest konsekwencją funkcjonującego samorządu, stąd też zasadniczym jest stwierdzenie, że samorząd terytorialny jest „przestrzenią" realizacji przez osobę jej twórczej podmiotowości. Stąd też samorząd terytorialny, którego uzasadnienie znajduje się w płaszczyźnie antropologiczno-personalistycznej, tzn. w płaszczyźnie godności człowieka, stoi w służbie człowieka - osoby ${ }^{47}$.

Dlatego wręcz oczywistym jest stwierdzenie Jana Pawła II: „Głównym bogactwem człowieka jest [...] sam człowiek. To właśnie jego inteligencja pozwala odkryć możliwości produkcyjne ziemi i różnorakie sposoby zaspokojenia ludzkich potrzeb. To jego zdyscyplinowana praca i solidarne współdziałanie $\mathrm{z}$ innymi umożliwia tworzenie coraz szerszych i coraz bardziej godnych zaufania wspólnot pracy, mających dokonywać przekształceń środowiska naturalnego i środowiska społecznego. Proces ten wymaga zaangażowania tak ważnych cnót, jak rzetelność, pracowitość, roztropność $\mathrm{w}$ podejmowaniu uzasadnionego ryzyka, wiarygodność, i wierność w relacjach międzyosobowych, męstwo we wprowadzaniu $\mathrm{w}$ życie decyzji trudnych i bolesnych, lecz koniecznych dla wspólnej pracy przedsiębiorstwa i dla zapobieżenia ewentualnym katastrofom" ${ }^{\prime 4}$.

Podmiotowość społeczności terytorialnej niejako z „natury” domaga się zagwarantowania i stworzenia warunków urzeczywistniania swej podmiotowości. Chodzi zatem o stworzenie i zabezpieczenie w strukturach państwowych odpowiedniej „płaszczyzny”, w której społeczność terytorialna $\mathrm{z}$ jednej strony będzie przeżywała swoją podmiotowość, tzn. ciągle i na nowo ją odkrywała i doświadczała, z drugiej zaś strony,

${ }^{46}$ A. Dylus, Zmienność i ciaggłość. Polskie transformacje ustrojowe w horyzoncie etycznym, Warszawa 1997, s. 117.

${ }^{47}$ Por. C. Ritter, Etos demokracji, s. 28-42.

${ }^{48}$ Jan Paweł II, Encyklika Centesimus annus, nr 32; por. T. Gruszecki, Przedsiębiorstwo (firma) i rynek we wspótczesnej ekonomii i w nauce społecznej Kościoła, w: Jan Paweł II, „Centesimus annus". Tekst i komentarze, red. F. Kampka, C. Ritter, Lublin 1998, s. 263-284. 
gdzie będzie rzeczywiście traktowana jako podmiot, a nie przedmiot życia społecznego.

A ponieważ doświadczenie i realizacja własnej podmiotowości jest możliwe tylko i wyłącznie z jednej strony w sferze autonomii i wolności, z drugiej zaś strony w sferze aktywnej działalności, chodzi ostatecznie o stworzenie takich struktur społeczno-polityczno-gospodarczych, które gwarantować będą faktyczną autonomię społeczności terytorialnej jako warunek realizacji podmiotowości, jak i płaszczyznę działalności, dzięki której owa podmiotowość może być realizowana. Wydaje się, że w dobie dzisiejszej, dobie globalizacji i unifikacyjnych tendencji, samorząd terytorialny zabezpieczając sferę autonomii oraz sferę aktywnej działalności, pozwala społeczności lokalnej realizować i urzeczywistniać swoją bytową podmiotowość.

\section{CONSIGLIO COMUNALE UNA VIA DI SOGGETTIVIZZAZIONE DELLE SOCIETÀ LOCALI}

\section{RIASSUNTO}

Consiglio comunale si mostra come una gestione degli affari propri da parte della gente di un territorio stabilito. Questi temi sono presenti nell'insegnamento sociale della Chiesa, particolarmente dal Concilio Vaticano II, anche se già prima si parlava del principio di sussidarietà. La cosa importante è quella di vedere fondamenti antropologico-personali del consiglio comunale. Allo stesso tempo bisogna sottolineare autonomie delle comunità locali. Dalla pratica risulta che il consiglio comunale diventa "luogo" oppure „ambiente" di realizzazione della soggettività della persona. Giovanni Paolo II scrive in "Centesimus annus": „C'e nel molteplice intersecarsi dei rapporti che vive la persona e cresce la «soggettività della società»" (49). 